\title{
Recent advances in preventing recurrent stroke [version 1;
}

\section{peer review: 3 approved]}

\section{J David Spence (iD}

Western University, and Stroke Prevention \& Atherosclerosis Research Centre, Robarts Research Institute, Ontario, Canada

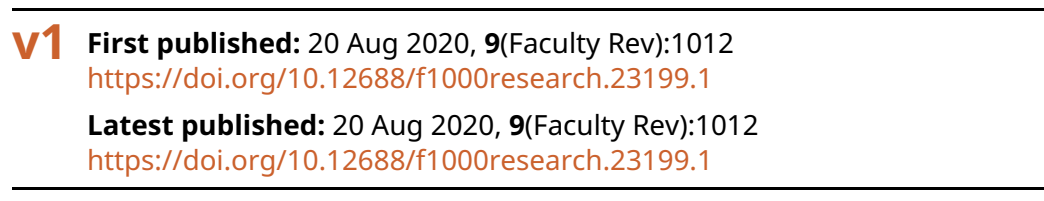

\section{Abstract}

Since a 2017 update, there have been important advances in stroke prevention. These include new evidence about nutrition, antiplatelet therapy, anticoagulation, lipid-lowering therapy, hypertension control, pioglitazone, and carotid endarterectomy and stenting. Evidence regarding toxic metabolites produced by the intestinal microbiome from egg yolk and red meat has important dietary implications, particularly for patients with impaired renal function, including the elderly. They should avoid egg yolk and red meat and limit the intake of animal flesh. Higher doses of folic acid may be needed for patients with the T allele of MTHFR, so it may not be sufficient to give vitamin B12 (methylcobalamin) alone, even in countries with folate fortification. There is now good evidence that lipid-lowering therapy is even more beneficial in the elderly than in younger patients; we should be using lipid-lowering therapy more intensively, often/usually combining statins with ezetimibe. There is new evidence that lower systolic blood pressure targets are better for most patients, but a subgroup with stiff arteries, a wide pulse pressure, and a diastolic pressure of $<60$ would be more likely to be harmed than helped by aiming for a systolic target of $<120 \mathrm{mmHg}$. There is a better understanding of how the pharmacological properties of direct-acting oral anticoagulants and the metabolism of antiplatelet agents should inform decisions about the use of these agents. Pioglitazone markedly reduces the risk of stroke, both in diabetics and prediabetics; it should be used more widely. It is now clear that carotid endarterectomy is safer than stenting and that the difference is strongly affected by age. Most patients, and in particular older patients, would be better served by endarterectomy than stenting.

\section{Keywords}

Stroke

\section{Open Peer Review}

$\begin{array}{rrr}\text { Approval Status } & \\ 1 & 2 & 3\end{array}$

\section{version 1}

20 Aug 2020

Faculty Reviews are review articles written by the prestigious Members of Faculty Opinions. The articles are commissioned and peer reviewed before publication to ensure that the final, published version is comprehensive and accessible. The reviewers who approved the final version are listed with their names and affiliations.

\section{Amytis Towfighi, University of Southern} California, Los Angeles, Los Angeles, USA

\section{Georgios Tsivgoulis, National and} Kapodistrian University of Athens, Athens, Greece

3. Craig S. Anderson, University of New South Wales, Sydney, Australia

Any comments on the article can be found at the end of the article. 
Corresponding author: J David Spence (dspence@robarts.ca)

Author roles: Spence JD: Conceptualization, Writing - Original Draft Preparation, Writing - Review \& Editing

Competing interests: The author is a consultant to Amgen and Orphan Technologies, and an unpaid officer of Vascularis Inc.

Grant information: The author(s) declared that no grants were involved in supporting this work.

Copyright: $\odot 2020$ Spence JD. This is an open access article distributed under the terms of the Creative Commons Attribution License, which permits unrestricted use, distribution, and reproduction in any medium, provided the original work is properly cited.

How to cite this article: Spence JD. Recent advances in preventing recurrent stroke [version 1; peer review: 3 approved] F1000Research 2020, 9(Faculty Rev):1012 https://doi.org/10.12688/f1000research.23199.1

First published: 20 Aug 2020, 9(Faculty Rev):1012 https://doi.org/10.12688/f1000research.23199.1 


\section{Introduction}

In a 2017 update $^{1}$, I discussed advances in hypertension, nutrition, anticoagulation, antiplatelet therapy, intracranial stenosis, percutaneous closure of patent foramen ovale, and lipidlowering therapy. Readers are invited to study that review. In this update, I discuss more recent developments in nutrition, hypertension, antiplatelet therapy, anticoagulation, lipid-lowering therapy, carotid endarterectomy (CEA) and carotid artery stenting (CAS). Exercise, smoking cessation, and adherence are also important, but there have been few recent advances in those topics. A report from the Insulin Resistance Intervention in Stroke (IRIS) trial reported a $34 \%$ reduction of stroke within 5 years among participants who quit smoking ${ }^{2}$. A Swedish study reported important improvements in risk scores, presumed to be a result of improved adherence, among patients with one or more risk factors attending a prevention program who were shown images of their carotid plaque ${ }^{3}$.

\section{Nutrition}

In 2017, I discussed the important advantages of the Mediterranean diet for stroke prevention. Since then, there have been developments regarding the consumption of cholesterol, meat, and eggs and the dietary implications of the interaction between renal function and the intestinal microbiome.

\section{Meat, cholesterol, and egg consumption}

Dietary cholesterol increases cardiovascular risk $^{4}$, so it seems obvious that, as egg yolk is very high in cholesterol content, the consumption of eggs would increase cardiovascular risk. Similarly, the consumption of meat, which is high in cholesterol and saturated fat, should also increase cardiovascular risk. This has been difficult to demonstrate, and indeed some observational studies suggest that egg and meat consumption are not harmful. Such findings are very likely based on indication bias and both measured and unmeasured confounders ${ }^{5}$ and are not biologically plausible. The reason it has been hard to demonstrate harm from eggs and meat is that the US diet is so bad that the AHA reported in 2015 that only $0.1 \%$ of Americans consume a healthy $\operatorname{diet}^{6}$. On that background, it is hard to show that anything makes it worse. On the other hand, in Greece, where the Mediterranean diet is the norm, the harm from egg consumption was more obvious. Among Greek diabetics, an egg a day increased coronary risk fivefold, and even 10 grams/day of egg (a sixth of a large egg) increased coronary risk by $54 \%{ }^{7}$.

Furthermore, besides cholesterol, egg yolk and red meat also contain high levels of dietary precursors of trimethylamine $\mathrm{N}$-oxide (TMAO). High levels of TMAO strongly predicted the 3-year risk of stroke/myocardial infarction/vascular death among $>4,000$ patients referred to the Cleveland Clinic for coronary angiography ${ }^{8}$. We reported in 2018 that plasma levels of TMAO and three other toxic metabolites produced by the intestinal microbiome were significantly higher in patients with severe atherosclerosis not predicted by risk factors ("unexplained atherosclerosis") than in patients with a protected phenotype (little or no carotid plaque despite high levels of coronary risk factors $)^{9}$. Hazen's group recently reported that phenylacetylglutamine increases cardiovascular risk via effects on adrenergic receptors ${ }^{10}$.

I recently reviewed evidence that vegetarian diets reduce cardiovascular risk. Perhaps the best evidence about this issue is presented by Zhong et al. ${ }^{11}$, who reported that, in the US, on the basis of data from 29,615 participants during a median follow-up of 17.5 years, both cholesterol consumption and egg consumption increased cardiovascular risk in a dose-dependent manner.

\section{Interaction of renal function and toxic metabolites of the intestinal microbiome}

Plasma levels not only of TMAO but also all of the toxic metabolites of the intestinal microbiome that we measured (TMAO, p-cresyl sulfate, hippuric acid, p-cresyl glucuronide, phenylacetylglutamine, and phenylsulfate), were significantly higher among study participants with an estimated glomerular filtration rate (eGFR) of $<66 \mathrm{~mL} /$ minute $/ 1.73 \mathrm{~m}^{212}$. Such levels of eGFR are the norm for patients aged over $75^{13}$. This means that patients with impaired renal function, including the elderly, should avoid egg yolk and red meat and limit their intake of animal flesh.

\section{B vitamins for lowering of homocysteine}

In the previous review ${ }^{1}$, I summarized evidence showing that $\mathrm{B}$ vitamins to lower homocysteine do indeed reduce the risk of stroke. In the early studies, harm from cyanocobalamin among participants with renal failure obscured the benefit. For that reason, we should use methylcobalamin instead of cyanocobalamin $^{14}$. I had been under the impression that folate fortification of the grain supply in North America meant that we needed to give only B12 supplements to reduce the risk of stroke. However, recent studies indicate that patients with the $T$ allele of methylene tetrahydrofolate reductase (MTHFR) probably need higher doses of folate than would be obtained from fortification of the grain supply ${ }^{15}$. This means that we will need to reconsider higher doses of folic acid in addition to B12 supplements and perhaps vitamin B6 and riboflavin ${ }^{16,17}$ as well. Further study is needed; a trial of methylcobalamin plus folic acid (and perhaps pyridoxine) versus placebo would be important though unlikely to be funded. Subgroups of patients most likely to benefit would be those with metabolic B12 deficiency, which is very common and usually missed, and patients with the $\mathrm{T}$ allele of MTHFR.

\section{Antiplatelet agents}

There are a couple of important developments in antiplatelet therapy. Grosser et al. ${ }^{18}$ reported that apparent "aspirin resistance" was due to enteric coating. We should probably be using chewable or uncoated aspirin, not coated aspirin.

The other major issue is that clopidogrel, a prodrug, requires activation by CYP2C19. Patients with a loss-of-function variant of CYP2C19 have reduced benefit of clopidogrel ${ }^{19}$. That loss-of-function variant is present in $230 \%$ of European and $>50 \%$ of Chinese patients. We probably should stop using 
clopidogrel and switch to prasugrel or ticlopidine. A recent study indicated that prasugrel was superior to ticlopidine ${ }^{20}$.

There have been a number of other advances in antiplatelet therapy, including combination of aspirin with rivaroxaban, as well as dual antiplatelet therapy for the prevention of recurrent stroke, which are not discussed here owing to word count limits.

\section{Anticoagulants}

Properties of direct-acting oral anticoagulants

Although there are not randomized controlled trial (RCT) head-to-head comparisons across the class of direct-acting oral anticoagulants (DOACs), there are important differences in their pharmacokinetic properties that should be considered in choosing which one to use. These are summarized in Table $1^{21}$.

Dabigatran is the most renally excreted of the DOACs, so it is unsuitable for patients with impaired renal function. Since the mean eGFR in patients older than 80 is $<60 \mathrm{~mL} /$ minute $/ 1.73 \mathrm{~m}^{213}$, this means that dabigatran is probably not a good choice for elderly patients. Dabigatran also has by far the lowest bioavailability, which makes it subject to large changes in blood levels with small changes in absorption or with drug interactions. It has a narrow therapeutic range, so it has been suggested that blood levels of dabigatran should probably be monitored ${ }^{22}$, thus negating one of the major advantages over warfarin. Rivaroxaban is not longer acting than the other DOACs, so it probably should not be administered once daily. Tellingly, recent studies with rivaroxaban have used twice-daily dosing ${ }^{23}$. As edoxaban also does not have a halflife longer than that of other DOACs, it too should probably not be taken once daily.
Vriejens and Heidbuchel reviewed the advantages of twicedaily dosing with apixaban vs. once-daily dosing with rivaroxaban. With twice-daily dosing, the blood levels of the drug stay within the therapeutic range throughout the day, instead of swinging from too high to too low, and there is less impact of a missed dose or an extra dose. One missed dose of rivaroxaban would be equivalent to missing three doses of apixaban, and an extra dose of rivaroxaban has a much bigger effect, with risk of bleeding, than an extra dose of apixaban ${ }^{24}$ (Figure 1).

This may account for recent reports that apixaban is less likely to cause GI bleeding than rivaroxaban ${ }^{25}$, more efficacious with regard to ischemic stroke or systemic embolism, and safer with regard to bleeding than rivaroxaban ${ }^{26}$. In a study comparing risk of hip fracture among patients taking warfarin vs. DOACs, apixaban had the lowest risk of hip fracture ${ }^{27}$.

\section{Misclassification of large artery atherosclerosis in embolic stroke of unknown source}

Antiplatelet agents are not anticoagulants; they prevent the aggregation of platelets in fast-flowing blood in arteries (white thrombus) but do not prevent "red thrombus", which forms in the setting of stasis, with fibrin polymerization and entrapped red blood cells ${ }^{28,29}$. For that reason, anticoagulants are more effective for preventing cardioembolic stroke.

In the past, when vitamin $\mathrm{K}$ antagonists such as warfarin were the only drugs available for anticoagulation, it was understandable that the paradigm would essentially be that one would never prescribe an anticoagulant without proving the presence of a cardioembolic source such as atrial fibrillation.

Table 1. Characteristics of direct-acting oral anticoagulants (DOACs).

\begin{tabular}{|l|l|l|l|l|}
\hline Characteristic & Rivaroxaban & Dabigatran & Apixaban & Edoxaban \\
\hline Target & Factor Xa & Factor Ila & Factor Xa & Factor Xa \\
\hline Prodrug & No & Yes & No & No \\
\hline Dosing & Once daily & Twice daily & Twice Daily & Once Daily \\
\hline Bioavailability & $80 \%-100 \%$ & $6.5 \%$ & $50 \%$ & $62 \%$ \\
\hline Half-life & $5-13$ hours & $12-14$ hours & $8-15$ hours & $10-14$ hours \\
\hline Renal clearance & $\sim 33 \%$ & $85 \%$ & $\sim 27 \%$ & $\sim 50 \%$ \\
\hline Cmax & $2-4$ hours & $1-2$ hours & $3-4$ hours & $1-2$ hours \\
\hline Interactions & $\begin{array}{l}\text { Strong inhibitors of CYP3A4 } \\
\text { and P-gp }\end{array}$ & P-gp inhibitors & $\begin{array}{l}\text { Strong inhibitors of } \\
\text { CYP3A4 and P-gp }\end{array}$ & $\begin{array}{l}\text { P-gp } \\
\text { inhibitors }\end{array}$ \\
\hline
\end{tabular}

CYP3A4, intestinal cytochrome P450 3A4; P-gp, P-glycoprotein.

This table was reproduced from Cardioembolic stroke: everything has changed, Spence JD, 3:76-83, $2018^{21}$ with permission from BMJ Publishing Group Ltd. 

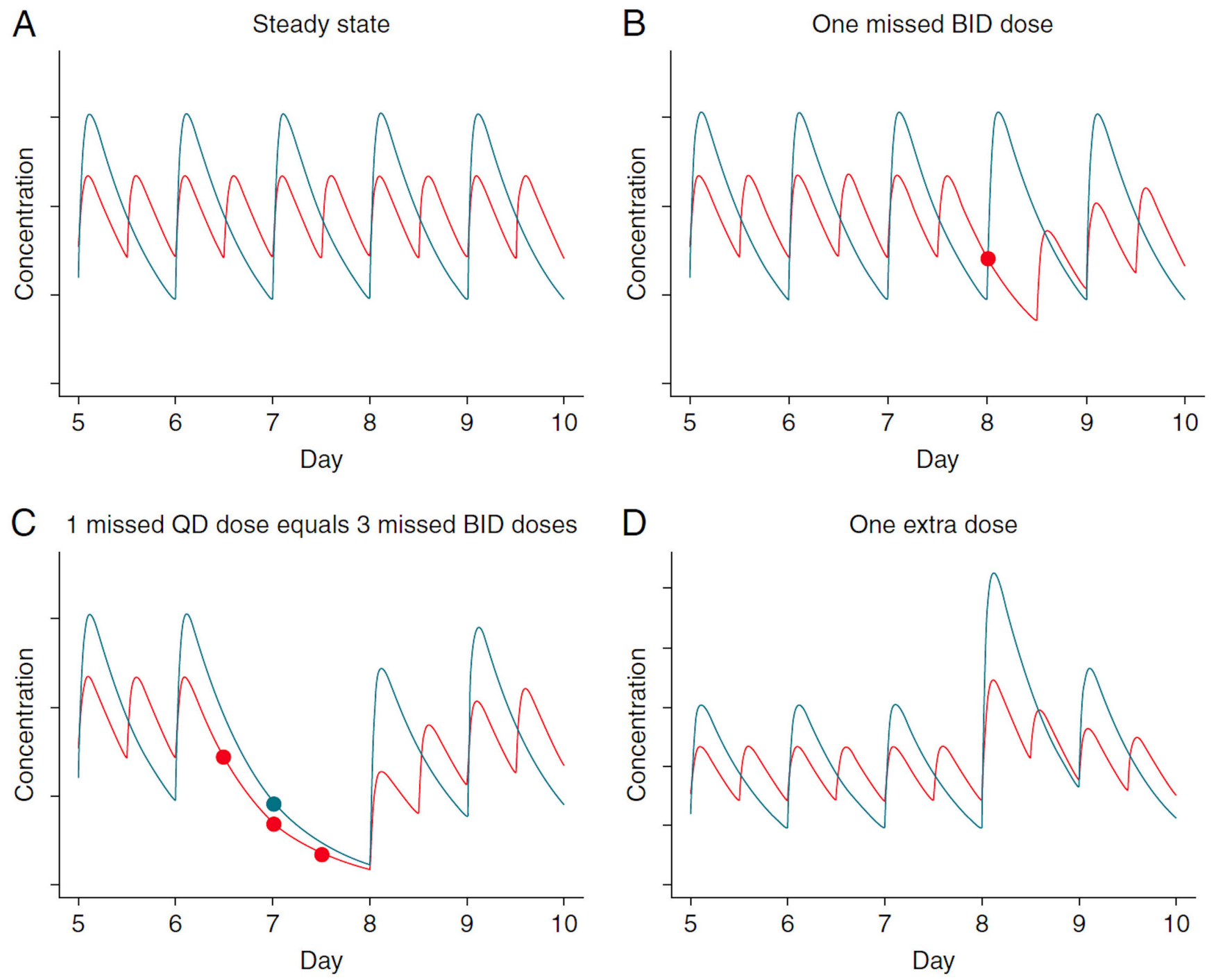

Figure 1. Once-daily vs. twice-daily dosing: difference between intake and predicted biological impact in general. Different patterns of non-adherence lead to different exposition to "risk" between once-daily and twice-daily drugs. These graphs illustrate the theoretical pharmacokinetic profiles of a dose X administered once-daily (QD) and a dose X/2 administered twice-daily (BID) for a drug with a half-life of about 12 hours and a Tmax of 3 hours. (A) The peak-to-trough ratio is much smaller for the BID than the QD dosing. (B) The concentration after a single missed BID dose (red dot) is similar to the expected trough concentration of QD dosing, suggesting that missing a single dose of a twice-daily dosing regimen should not be therapeutically critical. (C) The pharmacological equivalent of missing a single dose in a once-daily regimen (blue dot) is missing three consecutive doses (red dots) of a twice-daily dosing regimen. (D) Taking an extra dose results in a much higher peak for the QD than for the BID dosing regimen. This figure was reproduced from Heidbuchel H, Vrijens B. Non-vitamin k antagonist oral anticoagulants: Considerations on once- vs. Twice-daily regimens and their potential impact on medication adherence. EP Europace. 2015;17:1317-131824 by permission of Oxford University Press.

However, since DOACs are not significantly more likely than aspirin to cause severe bleeding ${ }^{30,31}$, the paradigm should change. There are good reasons to think that in patients in whom a cardioembolic source is strongly suspected, it would be more prudent to prescribe a DOAC than an antiplatelet agent ${ }^{32}$.

Several trials to test that hypothesis failed to show a benefit of anticoagulation in patients with embolic stroke of unknown source (ESUS); however, it is very likely that misclassification of large artery disease may have accounted for that. When large artery atherosclerosis (LAA) is defined as a 50\% carotid stenosis, it will miss $79 \%$ of patients classified as LAA by a high carotid plaque burden ${ }^{33}$. Since antiplatelet therapy is more efficacious in LAA, failing to exclude such patients may be why anticoagulation was not superior in ESUS. Importantly, a meta-analysis that was included in a substudy of one of those trials showed that anticoagulation was superior to antiplatelet therapy for patients with patent foramen ovale ${ }^{34}$. 


\section{Hypertension}

Physiologically individualized therapy based on renin/ aldosterone phenotyping

Reasons why physiologically individualized therapy based on renin/aldosterone phenotyping significantly improves blood pressure control ${ }^{35}$, discussed in the 2017 review, have become more apparent. The physiology of salt and water retention was reviewed in $2018^{36}$. A study of hypertension in foreign-born vs. US-born blacks revealed that African-Americans have nearly twice the rate of hypertension ${ }^{37}$, supporting the African Diaspora theory proposed by Grim $^{38}$ and others: the very high mortality rate during the Atlantic crossing in slave ships, from diarrhea, vomiting, and sweating in the heat below decks, created a selective advantage for genetic causes of salt and water retention. It is now apparent that at least six genetic variants predispose to a primary aldosteronism/inappropriate aldosterone secretion phenotype (low renin/low aldosterone), best treated with an aldosterone antagonist such as spironolactone or eplerenone, and at least six predispose to a Liddle phenotype (low renin/low aldosterone), best treated with amiloride ${ }^{39}$. An important cause of resistant hypertension is "Diagnostic Inertia" - failure to ask the question "What is the physiological driver of the hypertension in this patient?". Plasma renin and aldosterone should be measured in a stimulated condition (i.e. while taking a diuretic, angiotensin receptor antagonist, or angiotensin-converting enzyme inhibitor), and the results should be interpreted in light of the class(es) of medication being taken at the time of blood sampling ${ }^{40}$.

\section{Lower blood pressure targets in frail elderly patients}

In the wake of the Standard Trial of Intensive versus BloodPressure Control (SPRINT) trial, among participants with increased cardiovascular risk but without diabetes ${ }^{41}$, lower blood pressure targets (a systolic pressure of $<120 \mathrm{mmHg}$ ) are being recommended for blood pressure control. This approach may be well suited to most hypertensive patients, but there is an important exception. Patients with stiff arteries are at risk from systolic targets that are too low. The reasons include 1. stiff arteries widen pulse pressure, 2. stiff arteries increase the likelihood that the blood pressure measured by a cuff is actually much higher than the true (intra-arterial) pressure ${ }^{42}$, and 3. most of coronary perfusion ${ }^{43}$, and more than half of cerebral perfusion ${ }^{44}$, occurs during diastole. For that reason, patients with a diastolic pressure of $<60 \mathrm{mmHg}$ with a pulse pressure of $>60 \mathrm{mmHg}$ have a doubling of subclinical myocardial ischemia $^{43}$ and a 5.85 -fold increase in the risk of stroke ${ }^{45}$. Frail elderly patients with stiff arteries (a pulse pressure of $>60 \mathrm{mmHg}$ ) should not be treated to a target systolic pressure of $<120 \mathrm{mmHg}$. A 2019 meta-analysis of standard vs. intensive blood pressure control for secondary stroke prevention supported a blood pressure target of less than $130 / 80 \mathrm{mmHg}^{46}$.

\section{Lipid-lowering therapy}

A key part of stroke prevention is lipid-lowering therapy; this is particularly important in patients with LAA. Amarenco et al. recently reported that lower target LDL-C significantly reduced the risk of recurrent stroke ${ }^{47}$. Participants randomized to a lower target LDL-C of $<70 \mathrm{mg} / \mathrm{dL}(1.8 \mathrm{mmol} / \mathrm{L})$ vs. a target range of $90 \mathrm{mg}$ to $110 \mathrm{mg} / \mathrm{dL}$ ( 2.3 to $2.8 \mathrm{mmol} / \mathrm{L})$ had a significantly lower risk of the primary endpoint (ischemic stroke, myocardial infarction, new symptoms leading to urgent coronary or carotid revascularization, or death from cardiovascular causes; adjusted hazard ratio [HR] $0.78 ; 95 \%$ confidence interval [CI] $0.61-0.98 ; P=0.04)$. A frequently missed opportunity is in adding ezetimibe to statins; ezetimibe more than doubles the effect of statins, with fewer adverse effects than the use of highdose statins ${ }^{48}$. The recent European guidelines recommend the addition of ezetimibe in high-risk patients who do not achieve a target LDL-C of $140 \mathrm{mmol} / \mathrm{L}(53 \mathrm{mg} / \mathrm{dL})^{49}$. In the guideline, high risk was defined as having a previous cardiovascular event, but patients with asymptomatic carotid stenosis ${ }^{50}$, a high coronary calcium score $^{51}$, or a high carotid plaque burden ${ }^{52}$ are also at very high risk $^{52}$. A number of new lipid-lowering therapies are in development ${ }^{53}$.

Two other recent developments are from the 2019 European guideline on the management of dyslipidemia, with consensus guidelines recommending a lower target LDL-C of $1.4 \mathrm{mmol} / \mathrm{L}$ $(53 \mathrm{mg} / \mathrm{dL})$ and the use of ezetimibe in patients who do not achieve target levels with statin alone. Using ezetimibe with statins is an important measure. Because statins and ezetimibe work by different mechanisms, the combination is synergistic. Ezetimibe more than doubles the lowering of LDL-C by statins. In patients who do not tolerate full doses of statins, adding ezetimibe will achieve the effect of high-dose statins with fewer adverse effects (probably the only truly causal adverse effect of ezetimibe is loose bowel movements, rarely diarrhea).

The importance of keeping patients on their lipid-lowering therapy was shown in the 2020 trial by Amarenco et al. ${ }^{47}$. Patients with ischemic stroke and atherosclerosis were randomized to a lower target LDL-C of less than $1.8 \mathrm{mmol} / \mathrm{L}$ (70 mg/dL) vs. a target of 2.3 to $2.8 \mathrm{mmol} / \mathrm{L}$ ( $90 \mathrm{mg}$ to $110 \mathrm{mg} / \mathrm{dL})$. At sites where patients were in the target range for $>50 \%$ of the time, major cardiovascular events were reduced by $36 \%$ (HR 0.64 , 95\% CI 0.48-0.85); at sites where participants were at target $<50 \%$ of the time, there was no reduction in major cardiovascular events (HR 1.14, 95\% CI 0.75-1.73). There is a major problem with patients stopping statins for the wrong reasons (often influenced by internet nonsense). A review in $2016^{48}$ discussed approaches to helping patients stay on statins; adding ezetimibe is a cornerstone of that effort.

An important advance is that there is now good evidence that lipid-lowering therapy is even more beneficial in the elderly than in younger patients. I recently reviewed this issue ${ }^{54}$. In the past, there was a tendency to withhold statins in older patients on the basis that since patients over the age of 80 years were not enrolled in randomized trials, there was no direct evidence of benefit; but, then again, there was also no 
evidence of harm! As discussed by Mortensen and Falk ${ }^{55}$, because the elderly are at higher risk of cardiovascular events, the benefit of lipid lowering should be even greater in old patients than in younger patients, with a greater absolute risk reduction and a smaller number needed to treat (NNT). This has indeed been shown to be the case in an RCT of adding ezetimibe to simvastatin: the NNT in patients aged over 75 was only 11 vs. 125 in patients younger than 75. In an RCT in Japan, patients with a mean age of 80.6 years at baseline were randomized to diet alone or diet plus ezetimibe. Over a median follow-up of 4.1 years, there was a $34 \%$ reduction of composite cardiovascular events and a $40 \%$ reduction of combined coronary events ${ }^{56}$.

A scientific statement from the American Heart Association in 2019 reviewed the evidence that statins do not cause most of the adverse effects that have been attributed to them ${ }^{57}$. Collin et al. point out that most such putative adverse effects based on observational studies are the result of indication bias or confounders, and they are refuted by meta-analysis of randomized trials of statins in very large numbers of patients ${ }^{58}$. The GREACE trial established that patients with elevated liver enzymes actually do better if they continue statins; "transaminitis" is probably due to fatty liver ${ }^{59}$. The European Guideline ${ }^{49}$ now recommends against monitoring of liver function in patients on statins and against stopping statins on account of "transaminitis". I recently reviewed the issue of intracerebral hemorrhage $(\mathrm{ICH})$. The widespread belief that statins cause $\mathrm{ICH}$ was an artefact of an inappropriate intention-to-treat analysis of the Stroke Prevention by Aggressive Reduction in Cholesterol Levels (SPARCL) RCT, in which $25 \%$ of patients randomized to placebo crossed over to statin, and many patients randomized to statin stopped taking it. The proof that atorvastatin could not have caused ICH is that there was a greater reduction of ischemic stroke, but no increase in $\mathrm{ICH}$, among SPARCL participants who achieved a $50 \%$ reduction of LDL$\mathrm{C}$ (i.e. they were taking the medication) ${ }^{60}$. Even if there were a slight increase in ICH with statins, there would be far greater harm from withholding or stopping statins than continuing them ${ }^{61}$.

Lipid-lowering therapy should be intensive, should frequently (or usually) be combined with ezetimibe, and should not be withheld on account of age or misplaced fear of ICH. In some patients, if the very high cost is not an issue, therapies directed at proprotein convertase subtilisin/kexin type 9 (PCSK9) might be considered.

\section{Pioglitazone}

Diabetes and insulin resistance are risk factors for stroke. Pioglitazone, a weak agonist of peroxisome proliferator-activated receptor- $\alpha$ (PPAR- $\alpha)$ and a potent agonist of PPAR- $\gamma$, reduces insulin resistance and has anti-atherosclerotic effects ${ }^{62}$. In 2016, the IRIS trial reported a $23 \%$ reduction in recurrent stroke with pioglitazone over 5 years in the intention-to-treat analysis, but adherence was suboptimal in many patients, mainly because of fluid retention and weight gain.

A meta-analysis in 2017 reported a $42 \%$ reduction of recurrent stroke with pioglitazone among patients with stroke and diabetes, insulin resistance, or prediabetes ${ }^{63}$. In 2019, a substudy of the IRIS trial was conducted among participants with insulin resistance defined by a glycosylated hemoglobin (A1C) level of 5.7 to $6.4 \%$ or fasting plasma glucose level of 5.55 to $6.94 \mathrm{mmol} / \mathrm{L}(100 \mathrm{mg} / \mathrm{dL}$ to $125 \mathrm{mg} / \mathrm{dL})$. Among those with good adherence (taking $>80 \%$ of the protocol dose), stroke or myocardial infarction was reduced by $43 \%$ in 5 years, recurrent stroke was reduced by $36 \%$, and new-onset diabetes was reduced by $82 \%$ (Figure 2 ).

Pantoni, in an accompanying editorial ${ }^{64}$, noted that pioglitazone is probably underutilized, in part because of a probably unjustified belief that it increases the risk of bladder cancer. There is also a risk of fractures with pioglitazone, but the NNT to prevent one stroke or myocardial infarction with pioglitazone is only 24 , the NNT to prevent one case of new-onset diabetes is only 12 , and the number needed to harm $(\mathrm{NNH})$ to cause one serious fracture is $125^{62}$. Pioglitazone should be used more widely for stroke prevention, both in diabetes and in prediabetes/metabolic syndrome.

\section{Carotid endarterectomy and stenting}

Recent advances include two important meta-analyses. Brott et $a l .{ }^{65}$ reported from a pooled analysis of individual data from 4,754 participants in symptomatic carotid stenosis that CEA was superior to CAS; the risk of stroke or death or subsequent ipsilateral stroke with CEA was $2.8 \%$ (95\% CI 1.1-4.4) vs. $4.1 \%(2.0-6.3)$ with CAS at follow-up times up to 10 years. These outcomes were dominated by periprocedural events ${ }^{66}$. It is now clear from a meta-analysis by Howard et al. ${ }^{67}$ that CEA is preferable for most older patients (Figure 3). "CAS should be reserved for selected patients. Factors that would favour CAS could include younger age, specific anatomical features (such as a stenosis that is in the very distal internal carotid artery), lack of tortuosity of the arteries leading to the stenosis, absence of or only minimal plaque calcification, presence of local tissue scarring due to previous surgery or radiation, and conditions conferring a high medical risk for surgery (such as congestive heart failure, myocardial ischaemia, or severe pulmonary disease)" ${ }^{\natural 6}$. 
A Stroke or myocardial infarction

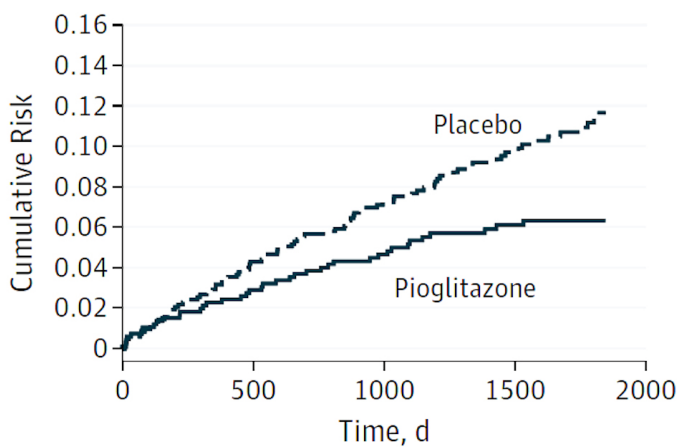

No. at risk

Pioglitazone $\quad 644 \quad 613 \quad 553 \quad 414$

$\begin{array}{lllll}\text { Placebo } & 810 & 752 & 660 & 470\end{array}$

C Acute coronary syndrome

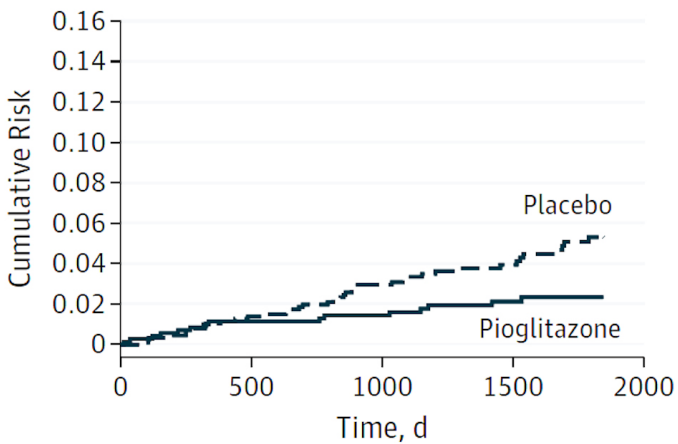

No. at risk

Pioglitazone $\quad \begin{array}{llll}644 & 623 & 569 & 430\end{array}$

$\begin{array}{lllll}\text { Placebo } & 810 \quad 772 & 682 & 492\end{array}$

E Diabetes

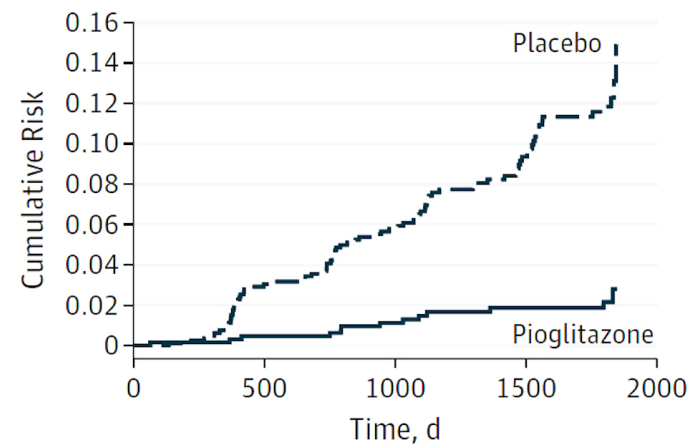

No. at risk

Pioglitazone $\quad 644 \quad 627 \quad 569 \quad 428$

$\begin{array}{lllll}\text { Placebo } & 810 & 760 & 662 & 461\end{array}$
B Stroke

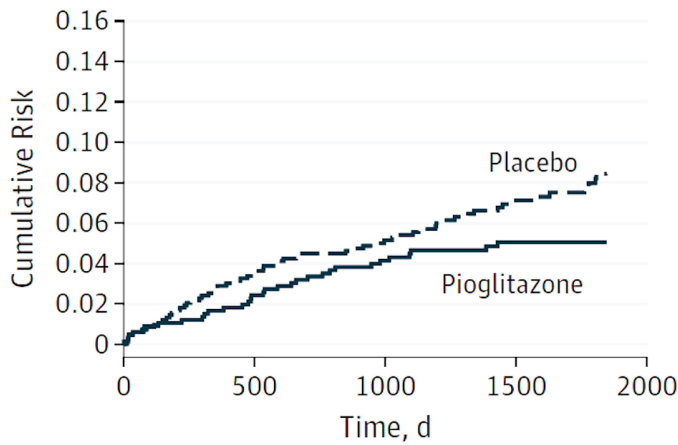

$\begin{array}{lllll}\text { No. at risk } & & & & \\ \text { Pioglitazone } & 644 & 615 & 555 & 415 \\ \text { Placebo } & 810 & 757 & 673 & 484\end{array}$

D Stroke/MI/HHF

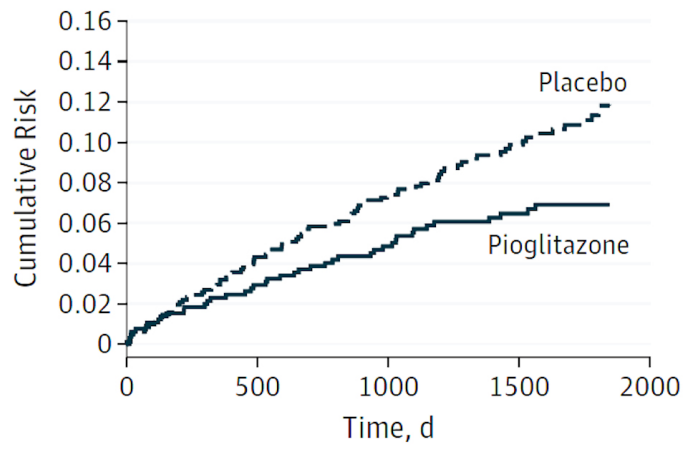

No. at risk

$\begin{array}{lllll}\text { Pioglitazone } & 644 & 613 & 553 & 413\end{array}$

$\begin{array}{lllll}\text { Placebo } & 810 & 752 & 660 & 470\end{array}$

Figure 2. Effect of pioglitazone in patients with stroke and prediabetes: results in patients who took $>80 \%$ of the protocol dose.

(A) Stroke or myocardial infarction (hazard ratio [HR] 0.57; 95\% confidence interval [CI] 0.39-0.84; $P=0.004$ ). (B) Stroke (HR 0.64; 95\% CI 0.42-0.99; $P$ = 0.04). (C) Acute coronary syndrome (HR 0.47; 95\% CI 0.26-0.85; $P=0.01$ ). (D) Stroke/myocardial infarction (MI)/hospitalization for heart failure (HHF) (HR 0.61; 95\% CI 0.42-0.88; $P=0.008$ ). (E) New-onset diabetes (HR 0.18; 95\% CI 0.10-0.33; $P<0.001$ ). This figure was reproduced from Spence JD, Viscoli CM, Inzucchi SE, Dearborn-Tomazos J, Ford GA, Gorman M, et al. Pioglitazone therapy in patients with stroke and prediabetes: A post hoc analysis of the iris randomized clinical trial. JAMA Neurol. 2019;76:526-535 $5^{62}$ with permission from the American Medical Association. 

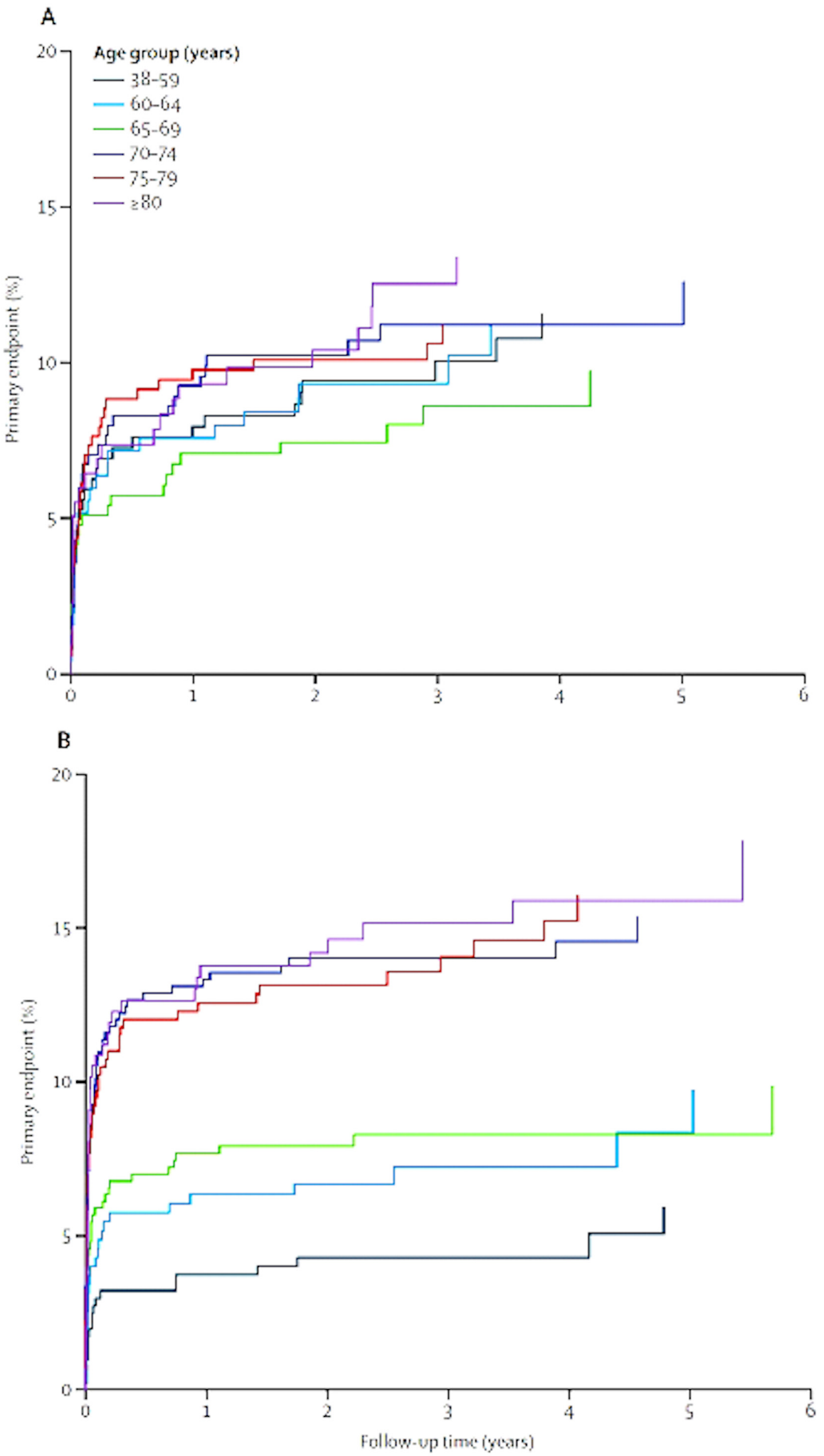

Figure 3. Estimated event rates for patients assigned to CEA (A) and CAS (B) by age stratum. The age groups are shown by the color key. Events plotted during the first 120-day periprocedural period include stroke in either hemisphere plus deaths, whereas events during the postprocedural period include ipsilateral stroke only. Patients were censored at 6 years for the graphical presentation of event rates. CAS, carotid artery stenting; CEA, carotid endarterectomy. This figure was reprinted from The Lancet, 387, Howard G, Roubin GS, Jansen O, Hendrikse J, Halliday A, Fraedrich G, et al., Association between age and risk of stroke or death from carotid endarterectomy and carotid stenting: A meta-analysis of pooled patient data from four randomised trials, 1305-1311., 2016 ${ }^{67}$ with permission from Elsevier. 


\section{Summary/conclusion}

What does the future hold? Probably advances in transcarotid stenting will show the benefit of this approach over transfemoral or transradial stenting. New therapies for cholesterol-lowering will probably also improve stroke prevention, as well as improvements in antiplatelet therapy. What questions remain? Ongoing RCTs of stenting vs. endarterectomy vs. intensive medical therapy will likely provide answers about asymptomatic stenosis that may be applicable to symptomatic carotid stenosis; also, we need further evidence about anticoagulation in ESUS when the misclassification of LAA has been addressed. There have been many recent advances in stroke prevention; no doubt more are to come.
1. Spence JD: Recent advances in preventing stroke recurrence [version 1; peer review: 2 approved]. F1000Res. 2017; 6: 1017. PubMed Abstract | Publisher Full Text | Free Full Text

2. Epstein KA, Viscoli CM, Spence JD, et al.: Smoking cessation and outcome after ischemic stroke or TIA. Neurology. 2017; 89(16): 1723-9. PubMed Abstract | Publisher Full Text | Free Full Text

3. Näslund $U, \mathrm{Ng} \mathrm{N}$, Lundgren $\mathrm{A}$, et al.: Visualization of asymptomatic atherosclerotic disease for optimum cardiovascular prevention (VIPVIZA): A pragmatic, open-label, randomised controlled trial. Lancet. 2019; 393(10167): 133-42.

PubMed Abstract | Publisher Full Text | Faculty Opinions Recommendation

4. Spence JD, Jenkins DJA, Davignon J: Dietary cholesterol and egg yolks: Not for patients at risk of vascular disease. Can J Cardiol. 2010; 26(9): e336-e339. PubMed Abstract | Publisher Full Text | Free Full Text

5. Spence JD, Jenkins D: Cardiovascular benefit of egg consumption is most unlikely. Heart. 2018; 104(21): 1805-6.

PubMed Abstract | Publisher Full Text

6. Mozaffarian D, Benjamin EJ, Go AS, et al.: Heart disease and stroke statistics-2015 update: a report from the American Heart Association. Circulation. 2015; 131(4): e29-322

PubMed Abstract | Publisher Full Text

7. Trichopoulou A, Psaltopoulou T, Orfanos P, et al.: Diet and physical activity in relation to overall mortality amongst adult diabetics in a general population cohort. J Intern Med. 2006; 259(6): 583-91. PubMed Abstract | Publisher Full Text

8. Tang WHW, Wang Z, Levison BS, et al.: Intestinal microbial metabolism of phosphatidylcholine and cardiovascular risk. N Engl J Med. 2013; 368(17): 1575-84.

PubMed Abstract | Publisher Full Text | Free Full Text | Faculty Opinions Recommendation

9. Bogiatzi C, Gloor G, Allen-Vercoe E, et al.: Metabolic products of the intestinal microbiome and extremes of atherosclerosis. Atherosclerosis. 2018; 273 : micro

91-7.
PubMed Abstract | Publisher Full Text

10. Nemet I, Saha PP, Gupta N, et al.: A Cardiovascular Disease-Linked Gut Microbial Metabolite Acts via Adrenergic Receptors. Cell. 2020; 180(5): 862-877.e22.

PubMed Abstract | Publisher Full Text | Free Full Text | Faculty Opinions Recommendation

11. Zhong VW, van Horn L, Cornelis MC, et al.: Associations of Dietary Cholesterol or Egg Consumption With Incident Cardiovascular Disease and Mortality. JAMA. 2019; 321(11): 1081-1095.

PubMed Abstract | Publisher Full Text | Free Full Text | Faculty Opinions Recommendation

12. Pignanelli $M$, Bogiatzi $C$, Gloor G, et al: Moderate Renal Impairment and Toxic Metabolites Produced by the Intestinal Microbiome: Dietary Implications. J Ren Nutr. 2019; 29(1): 55-64. PubMed Abstract | Publisher Full Text

13. Spence JD, Urquhart BL, Bang $\mathrm{H}$ : Effect of renal impairment on atherosclerosis: Only partially mediated by homocysteine. Nephrol Dial Transplant. 2016; 31(6): 937-44.

PubMed Abstract | Publisher Full Text | Free Full Text

14. Spence JD, Yi Q, Hankey GJ: B vitamins in stroke prevention: Time to reconsider. Lancet Neurol. 2017; 16(9): 750-60. PubMed Abstract | Publisher Full Text

15. Qin X, Spence JD, Li J, et al.: Interaction of serum vitamin $B_{12}$ and folate with MTHFR genotypes on risk of ischemic stroke. Neurology. 2020; 94(11): e1126-e1136.

PubMed Abstract | Publisher Full Text | Free Full Text

16. McNulty H, Le Dowey RC, Strain J], et al.: Riboflavin Lowers Homocysteine in Individuals Homozygous for the MTHFR $677 \mathrm{C} \rightarrow$ T Polymorphism. Circulation 2006; 113(1): 74-80.

PubMed Abstract | Publisher Full Text
17. McNulty H, Strain JJ, Hughes CF, et al.: Riboflavin, MTHFR genotype and blood pressure: A personalized approach to prevention and treatment of hypertension. Mol Aspects Med. 2017; 53: 2-9.

PubMed Abstract | Publisher Full Text

18. Grosser T, Fries S, Lawson JA, et al.: Drug resistance and pseudoresistance: an unintended consequence of enteric coating aspirin. Circulation. 2013; 127(3): 377-85.

PubMed Abstract | Publisher Full Text | Free Full Text | Faculty Opinions Recommendation

19. Wang Y, Zhao X, Lin J, et al.: Association Between CYP2C19 Loss-of-Function Allele Status and Efficacy of Clopidogrel for Risk Reduction Among Patients With Minor Stroke or Transient Ischemic Attack. JAMA. 2016; 316(1): 70-8. PubMed Abstract | Publisher Full Text

20. Schüpke S, Neumann F, Menichelli M, et al.: Ticagrelor or Prasugrel in Patients with Acute Coronary Syndromes. N EnglJ Med. 2019; 381(16): 1524-1534.

PubMed Abstract | Publisher Full Text | Faculty Opinions Recommendation

21. Spence JD: Cardioembolic stroke: Everything has changed. Stroke VasC Neurol. 2018; 3(2): 76-83.

PubMed Abstract | Publisher Full Text | Free Full Text

22. Reilly PA, Lehr T, Haertter S, et al:: The effect of dabigatran plasma concentrations and patient characteristics on the frequency of ischemic stroke and major bleeding in atrial fibrillation patients: the RE-LY Trial (Randomized Evaluation of Long-Term Anticoagulation Therapy).J Am Coll (Randomized Evaluation of

PubMed Abstract | Publisher Full Text | Faculty Opinions Recommendation

23. Anand SS, Bosch J, Eikelboom JW, et al.: Rivaroxaban with or without aspirin in patients with stable peripheral or carotid artery disease: An international, randomised, double-blind, placebo-controlled trial. Lancet. 2018; 391(10117): 219-29.

PubMed Abstract | Publisher Full Text

24. Heidbuchel $\mathrm{H}$, Vrijens $\mathrm{B}$ : Non-vitamin $\mathrm{K}$ antagonist oral anticoagulants (NOAC): Considerations on once- vs. twice-daily regimens and their potential impact on medication adherence. Europace. 2015; 17(8): 1317-8. PubMed Abstract | Publisher Full Text

25. Abraham NS, Noseworthy PA, Yao X, et al.: Gastrointestinal Safety of Direct Oral Anticoagulants: A Large Population-Based Study. Gastroenterology. 2017; 152(5): 1014-1022.e1.

PubMed Abstract | Publisher Full Text

26. Fralick M, Colacci M, Schneeweiss S, et al.: Effectiveness and Safety of Apixaban Compared With Rivaroxaban for Patients With Atrial Fibrillation in Routine Practice: A Cohort Study. Ann Intern Med. 2020; 172(7): 463-73. PubMed Abstract | Publisher Full Text | Faculty Opinions Recommendation

27. Lutsey PL, Norby FL, Ensrud KE, et al.: Association of Anticoagulant Therapy With Risk of Fracture Among Patients With Atrial Fibrillation. JAMA Intern Med. 2020; 180(2): 245-253.

PubMed Abstract | Publisher Full Text | Free Full Text |

Faculty Opinions Recommendation

28. Deykin D: Thrombogenesis. N EnglJ Med. 1967; 276(11): 622-8. PubMed Abstract | Publisher Full Text

29. Caplan LR, Fisher M: The endothelium, platelets, and brain ischemia. Rev Neurol Dis. 2007; 4(3): 113-21. PubMed Abstract

30. Connolly SJ, Eikelboom J, Joyner C, et al: Apixaban in Patients with Atrial Fibrillation. N EnglJ Med. 2011; 364(9): 806-17. PubMed Abstract | Publisher Full Text | Faculty Opinions Recommendation

31. W Weitz JI, Lensing AWA, Prins MH, et al:: Rivaroxaban or Aspirin for Extended Treatment of Venous Thromboembolism. N EnglJ Med. 2017; 376(13): 1211-22

PubMed Abstract | Publisher Full Text | Faculty Opinions Recommendation

32. Spence JD: Anticoagulation in patients with Embolic Stroke of Unknown Source. Int J Stroke. 2019; 14(4): 334-6.

PubMed Abstract | Publisher Full Text 
33. Bogiatzi C, Wannarong T, McLeod AI, et al.: SPARKLE (Subtypes of Ischaemic Stroke Classification System), Incorporating Measurement of Carotid Plaque Burden: A New Validated Tool for the Classification of Ischemic Stroke Subtypes. Neuroepidemiology. 2014; 42(4): 243-51. PubMed Abstract | Publisher Full Text

34. Kasner SE, Swaminathan B, Lavados $\mathrm{P}$, et al.: Rivaroxaban or aspirin for patent foramen ovale and embolic stroke of undetermined source: $A$ prespecified subgroup analysis from the NAVIGATE ESUS trial. Lancet Neurol. 2018; 17(12): 1053-60.

PubMed Abstract | Publisher Full Text | Free Full Text

35. Akintunde A, Nondi J, Gogo K, et al.: Physiological Phenotyping for Personalized Therapy of Uncontrolled Hypertension in Africa. Am Hypertens. 2017; 30(9): 923-30. PubMed Abstract | Publisher Full Text

36. Spence JD, Rayner BL: Hypertension in Blacks: Individualized Therapy Based on Renin/Aldosterone Phenotyping. Hypertension. 2018; 72(2): 263-9. PubMed Abstract | Publisher Full Text

37. Spence JD: Hypertension in US-born vs. foreign-born African-Americans. J Hypertens. 2017; 35(12): 2369-71.

PubMed Abstract | Publisher Full Text

38. Grim CE, Robinson M: Salt, slavery and survival- hypertension in the African diaspora. Epidemiology. 2003; 14(1): 120-2. PubMed Abstract | Publisher Full Text

39. Spence JD: Hypertension in Africa. Eur J Prev Cardiol. 2019; 26(5): 455-7. PubMed Abstract | Publisher Full Tex

40. Huang $X$, Li J, Liu L, et al.: Interpreting stimulated plasma renin and aldosterone to select physiologically individualized therapy for resistant hypertension: Importance of the class of stimulating drugs. Hypertens Res. 2019; 42(12): 1971-1978. PubMed Abstract | Publisher Full Text

41. N Wright JT, Williamson JD, Whelton PK, et al:: A Randomized Trial of Intensive versus Standard Blood-Pressure Control. N EnglJ Med. 2015; 373(22): 2103-16.

PubMed Abstract | Publisher Full Text | Free Full Text Faculty Opinions Recommendation

42. Finnegan TP, Spence JD, Wong DG, et al.: Blood pressure measurement in the elderly: Correlation of arterial stiffness with difference between intraarterial and cuff pressures. J Hypertens. 1985; 3(3): 231-5. PubMed Abstract | Publisher Full Text

43. N McEvoy JW, Chen Y, Rawlings A, et al:: Diastolic Blood Pressure, Subclinical Myocardial Damage, and Cardiac Events: Implications for Blood Pressure Control. J Am Coll Cardiol. 2016; 68(16): 1713-22 PubMed Abstract | Publisher Full Text | Free Full Text | Faculty Opinions Recommendation

44. Spence JD: Spectral analysis of carotid vs femoral doppler velocity patterns: A clue to genesis of flow disturbances in cerebral arteries. Frontiers of Engineering in Health Care. 1981; 0000-0355.

45. Park JH, Ovbiagele B: Post-stroke diastolic blood pressure and risk of recurrent vascular events. Eur J Neurol. 2017; 24(11): 1416-23. PubMed Abstract | Publisher Full Text | Free Full Text

46. Nitagawa K, Yamamoto $\mathrm{Y}$, Arima $\mathrm{H}$, et al.: Effect of Standard vs Intensive Blood Pressure Control on the Risk of Recurrent Stroke: A Randomized Clinical Trial and Meta-analysis. JAMA Neurol. 2019; 76(11): 1309. PubMed Abstract | Publisher Full Text | Free Full Text | Faculty Opinions Recommendation

47. Amarenco P, Kim JS, Labreuche J, et al.: A Comparison of Two LDL Cholesterol Targets after Ischemic Stroke. N EnglJ Med. 2020; 382(1): 9. PubMed Abstract | Publisher Full Text | Faculty Opinions Recommendation

48. Spence JD, Dresser GK: Overcoming Challenges With Statin Therapy. J Am Heart Assoc. 2016; 5(1): e002497.

PubMed Abstract | Publisher Full Text | Free Full Text

49. Mach F, Baigent C, Catapano AL, et al.: 2019 esc/eas guidelines for the management of dyslipidaemias: Lipid modification to reduce cardiovascular risk: The task force for the management of dyslipidaemias of the european society of cardiology (esc) and european atherosclerosis society (eas). Eur Heart J. 2019.

50. Chimowitz MI, Weiss DG, Cohen SL, et al:: Cardiac prognosis of patients with carotid stenosis and no history of coronary artery disease. Veterans Affairs Cooperative Study Group 167. Stroke. 1994; 25(4): 759-65. PubMed Abstract | Publisher Full Text
51. Greenland P, Blaha MJ, Budoff MJ, et al.: Coronary Calcium Score and Cardiovascular Risk. J Am Coll Cardiol. 2018; 72(4): 434-47. Publisher Full Text | Faculty Opinions Recommendation

52. Spence JD, Eliasziw M, DiCicco M, et al.: Carotid plaque area: a tool for targeting and evaluating vascular preventive therapy. Stroke. 2002; 33(12): 2916-22. PubMed Abstract | Publisher Full Text

53. Hegele RA, Tsimikas S: Lipid-Lowering Agents. Circ Res. 2019; 124: $386-404$

Reference Source | Faculty Opinions Recommendation

54. Spence JD: The need for clinical judgement in the application of evidencebased medicine. BMJ EBM. 2019; bmjebm-2019-111300. PubMed Abstract | Publisher Full Text

55. Mortensen MB, Falk E: Primary Prevention With Statins in the Elderly. Am Coll Cardiol. 2018; 71(1): 85-94. PubMed Abstract | Publisher Full Text | Faculty Opinions Recommendation

56. N Ouchi Y, Sasaki J, Arai H, et al.: Ezetimibe Lipid-Lowering Trial on Prevention of Atherosclerotic Cardiovascular Disease in $\mathbf{7 5}$ or Olde (EWTOPIA 75): A Randomized, Controlled Trial. Circulation. 2019; 140(12): 992-1003.

PubMed Abstract | Publisher Full Text | Faculty Opinions Recommendation

57. Newman CB, Preiss D, Tobert JA, et al.: Statin Safety and Associated Adverse Events: A Scientific Statement From the American Heart Association. Arterioscler Thromb Vasc Biol. 2019; 39(2): e38-e81.

PubMed Abstract | Publisher Full Text | Faculty Opinions Recommendation

58. Collins R, Reith C, Emberson J, et al.: Interpretation of the evidence for the efficacy and safety of statin therapy. Lancet. 2016; 388(10059): 2532-61. PubMed Abstract | Publisher Full Text | Faculty Opinions Recommendation

59. Athyros VG, Tziomalos K, Gossios TD, et al.: Safety and efficacy of longterm statin treatment for cardiovascular events in patients with coronary heart disease and abnormal liver tests in the Greek Atorvastatin and Coronary Heart Disease Evaluation (GREACE) Study: A post-hoc analysis. Lancet. 2010; 376(9756): 1916-22.

PubMed Abstract | Publisher Full Text | Faculty Opinions Recommendation

60. Amarenco P, Goldstein LB, Szarek M, et al.: Effects of intense low-density lipoprotein cholesterol reduction in patients with stroke or transient ischemic attack: The Stroke Prevention by Aggressive Reduction in Cholesterol Levels (SPARCL) trial. Stroke. 2007; 38(12): 3198-204. PubMed Abstract | Publisher Full Text

61. Nudge C, Ruttledge S, Costello M, et al:: Lipid Lowering Therapy, LowDensity Lipoprotein Level and Risk of Intracerebral Hemorrhage - A MetaAnalysis. J Stroke Cerebrovasc Dis. 2019; 28(6): 1703-9. PubMed Abstract | Publisher Full Text | Faculty Opinions Recommendation

62. Spence JD, Viscoli CM, Inzucchi SE, et al.: Pioglitazone Therapy in Patients With Stroke and Prediabetes: A Post Hoc Analysis of the IRIS Randomized Clinical Trial. JAMA Neurol. 2019; 76(5): 526-35. PubMed Abstract | Publisher Full Text | Free Full Text

63. Lee M, Saver JL, Liao HW, et al.: Pioglitazone for Secondary Stroke Prevention: A Systematic Review and Meta-Analysis. Stroke. 2017; 48(2): 388-93.

PubMed Abstract | Publisher Full Text | Faculty Opinions Recommendation

64. Pantoni L: Potential New Horizons for the Prevention of Cerebrovascular Diseases and Dementia. JAMA Neurol. 2019; 76(5): 521-2. PubMed Abstract | Publisher Full Text | Faculty Opinions Recommendation

65. Brott TG, Calvet D, Howard G, et al.: Long-term outcomes of stenting and endarterectomy for symptomatic carotid stenosis: A preplanned pooled analysis of individual patient data. Lancet Neurology. 2019; 18(4): 348-56. PubMed Abstract | Publisher Full Text | Free Full Text | Faculty Opinions Recommendation

66. Spence JD: Periprocedural events dominate outcomes of carotid stenting and endarterectomy. Lancet Neurol. 2019; 18(4): 321-2. PubMed Abstract | Publisher Full Text

67. H Howard G, Roubin GS, Jansen O, et al:: Association between age and risk of stroke or death from carotid endarterectomy and carotid stenting: A meta-analysis of pooled patient data from four randomised trials. Lancet. 2016; 387(10025): 1305-11.

PubMed Abstract | Publisher Full Text | Faculty Opinions Recommendation 


\section{Open Peer Review}

\section{Current Peer Review Status:}

\section{Editorial Note on the Review Process}

Faculty Reviews are review articles written by the prestigious Members of Faculty Opinions. The articles are commissioned and peer reviewed before publication to ensure that the final, published version is comprehensive and accessible. The reviewers who approved the final version are listed with their names and affiliations.

\section{The reviewers who approved this article are:}

\section{Version 1}

\section{Craig S. Anderson}

George Institute for Global Health, University of New South Wales, Sydney, NSW, Australia

Competing Interests: No competing interests were disclosed.

\section{Georgios Tsivgoulis}

Second Department of Neurology, National and Kapodistrian University of Athens, Athens, Greece

Competing Interests: No competing interests were disclosed.

\section{Amytis Towfighi}

Division of Stroke and Neurocritical Care, Department of Neurology, University of Southern California, Los Angeles, Los Angeles, CA, USA

Competing Interests: No competing interests were disclosed.

The benefits of publishing with F1000Research:

- Your article is published within days, with no editorial bias

- You can publish traditional articles, null/negative results, case reports, data notes and more

- The peer review process is transparent and collaborative

- Your article is indexed in PubMed after passing peer review

- Dedicated customer support at every stage

For pre-submission enquiries, contact research@f1000.com 